\title{
Pimpinella tragium Vill. subsp. lithophila (Schischk.) Tutin (Apiaceae), a new taxon in Croatian flora
}

\author{
SANDRo Bogdanović ${ }^{1} *$, Mirko RuščIĆ ${ }^{2}$ \\ ${ }^{1}$ University of Zagreb, Faculty of Science, Department of Botany and Botanical \\ Garden, Marulićev trg 9a, 10000 Zagreb, Croatia \\ ${ }^{2}$ University of Split, Faculty of Philosophy, Teslina 12, 21000 Split, Croatia \\ A new member of the Croatian flora, Pimpinella tragium Vill. subsp. lithophila (Schischk.) \\ Tutin (Apiaceae), was found on the island of Vis in the Central Adriatic. It grows on the \\ calcareous rocky coast near the sea and is a member of a halophilous community within \\ the Crithmo-Limonion Br.-Bl. et Molinier 1934 alliance. Morphological similarities \\ within the Pimpinella tragium group are briefly discussed. A determination key is given \\ for all Croatian Pimpinella taxa.
}

Keywords: Pimpinella, taxonomy, flora, Island of Vis, Adriatic, Croatia

\section{Introduction}

The genus Pimpinella L. (Apiaceae) is represented by approximately 150 species in Europe, Asia and Africa. These are annual, biennial and perennial species, usually growing on dry rocky places rocky crevices, fields, meadows, mountain pastures and grasslands (Hartvig 1968, Tutin 1968 a, Pignatti 1982, Velayos 2003). In the Croatian flora according to Hirc (1908), Degen (1937), DomaC (1994: 235), LuKaČ (1997:113) and Flora Croatica database (Nikolić 2010) the genus Pimpinella is represented by seven taxa. These are P. alpina Host, P. anisum L., P. major (L.) Huds., P. peregrina L., P. saxifraga L., P. tragium Vill. and P. tragium Vill. subsp. polyclada (Boiss. et Heldr.) Tutin. Among them is $P$. tragium Vill. which is distributed in the Mediterranean area from Spain to Lebanon, north-west Africa, Asia Minor, the Caucasus, and in the south of the East European Plain (YuRTSEVA and TikHomirov 1998). In the countries and territories around Croatia and the Adriatic basin, P. tragium has been noted for Italy (PignatTi 1982, Conti et al. 2005), Serbia (SARić and Diklić 1986), Macedonia (MATEVSKi 2005), Bosnia and Herzegovina (Beck-Mannagetta 1927), Montenegro (Rohlena 1942), Albania (Qosja et al. 1992) and Greece (HARTVIG 1968).

* Corresponding author, e-mail: sandro@botanic.hr

Copyright $^{\circledR} 2011$ by Acta Botanica Croatica, the Faculty of Science, University of Zagreb.

All rights reserved. 
Pimpinella tragium represents a variable group of taxa with great morphological variability and confused taxonomy (TUTIN $1968 \mathrm{a}, \mathrm{b}$; YURTSEVA and TIKHOMIROV 1998). Some authors (Tutin 1968 a, b; MatTHews 1972; ENGSTRAND 1987; BRUllo and BRUllo 2009) distinguish several subspecies within this group: P. tragium subsp. lithophila (Schischk.) Tutin distributed in Southern Europe, Crimea, Turkey and Iran, P. tragium subsp. depressa (Sieber ex Spreng.) Tutin from Crete, P. tragium subsp. pseudotragium (DC.) Matthews from Turkey, Iran, Armenia and Iraq, P. tragium subsp. titanophila (Woronow) Tutin from East Europe, P. tragium subsp. polyclada (Boiss. et Heldr.) Tutin from the Balkans and Asia Minor and P. tragium subsp. glauca (C. Presl) C. Brullo et Brullo from Sicily.

\section{Materials and methods}

Field research on the Central Adriatic island of Vis was undertaken from 2007 to 2010. For determination of plant species we used relevant taxonomic literature (HARTVIG 1968; Tutin 1968 a, b; Pignatti 1982; Velayos 2003; Matevski 2005). All the localities from herbaria, literature data and field observations were geocoded in the Flora Croatica database (NIKOLIĆ 2010). The positions of the localities of Pimpinella tragium subsp. lithophila were determined by GPS Garmin eTrex Vista and a distribution map of the newly recorded taxon was produced by combined usage of ESRI GIS ArcMap 9.2 tool and the Flora Croatica database (NikOLIĆ 2010). Voucher specimens of P. tragium subsp. lithophila are deposited in CNHM and ZA herbarium.

\section{Results}

A new taxon, Pimpinella tragium subsp. lithophila (Fig. 1 a) was found within halophytic vegetation on the northern side of the island of Vis, in the vicinity of the village Oključina and of the town of Vis.

\section{Description}

Pimpinella tragium Vill. subsp. lithophila (Schischk.) Tutin in Feddes Repert. 79 (1-2): 62 (1968).

Synonyms: Pimpinella lithophila Schischk., Not. Syst. (Leningrad) 12: 206 (1950), Pimpinella tragium var. typica Halácsy, Concept. Fl. Graec. 1: 682 (1901).

Plant perennial, up to $60(-100) \mathrm{cm}$ high, pubescent or crisped-tomentose, rarely glabrescent or glabrous. Stems erect, basal parts form rhizomes covered by numerous scale-like remains of petioles. Rosette leaves numerous, basal leaves 5-25 cm long, long petiolate, oblong, ovate in outline, pinnatisect or bipinnatisect, with 3-7 pairs of segments, segments cuneate, ovate or orbiculate, crenate to deeply dentate. Upper cauline leaves vaginate with small sessile reduced lamina, usually reduced to a sheath. Umbels with $5-15(-20)$ unequal rays, densely or sparsely pubescent. Bracts and bracteoles absent or 1-2. Umbellula with 10-20 white flowers, sometimes pinkish; petals to $1 \mathrm{~mm}$ long, hairy on dorsal surface. Fruit 2-3 mm long, ovoid, densely tomentose, hairs short (Fig. 1 b). Stylopodium cushion-shaped, hemispherical, stylodium 1-2.5 mm long. Flowering time from Jun to August. Chromosome number: $2 n=20$. Life form: Chamaephyte. 

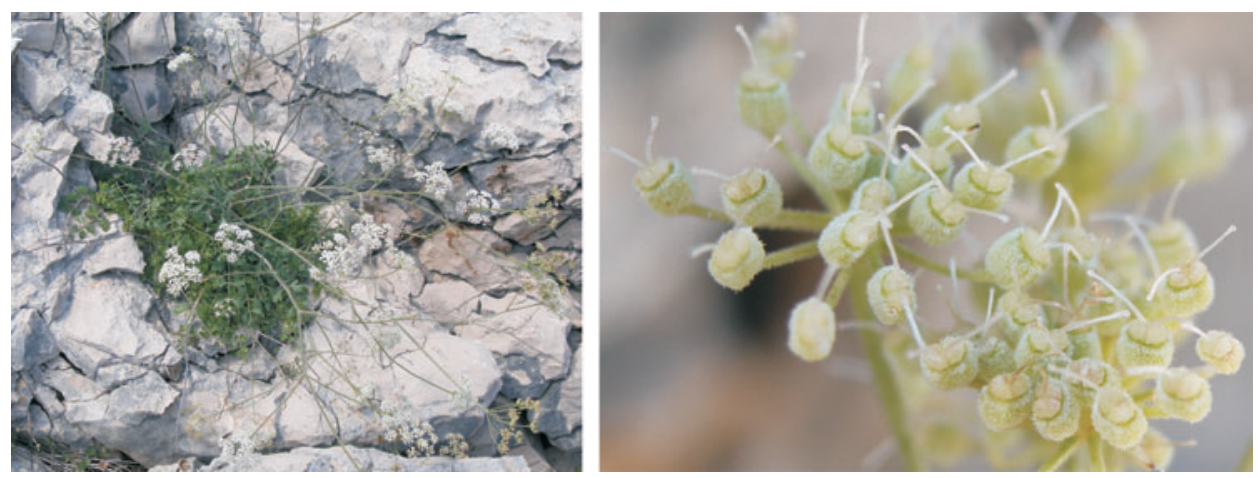

Fig. 1. Pimpinella tragium subsp. lithophila. $\mathrm{a}$ - habit on the island of Vis, $\mathrm{b}$ - tomentose ovaries (young fruits) (Photo by S. Bogdanović).

Distribution in Croatia: Central Adriatic, Dalmatia, Island of Vis (Fig. 2).

Specimina Visa: Croatia: Island of Vis, Tiha Inlet, Slatina Inlet rocky shore, May 18, 2008, Ruščić s.n. (ZA); Island Vis, Tiha Inlet rocky shore near Oključina, June 15, 2008, Bogdanović and Ruščić, s.n. (CNHM, ZA); Island of Vis, Dobra Inlet shore, June 15, 2008, Bogdanović and Rušcić, s.n. (CNHM, ZA); Island of Vis, Mala Travna Inlet rocky shore near Oključine, June 12, 2010, Bogdanović and Boršić s.n. (ZA).

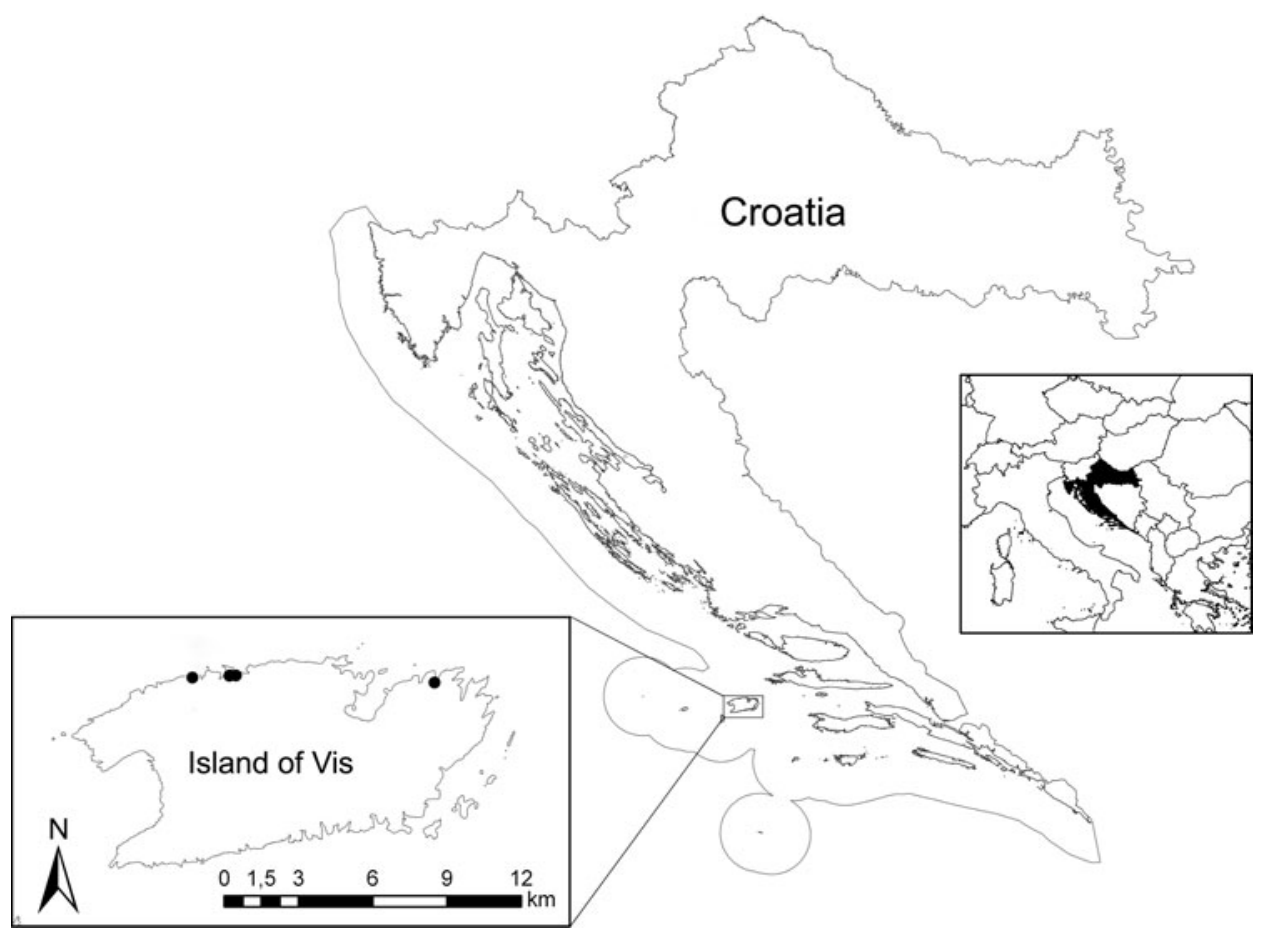

Fig. 2. Distribution of Pimpinella tragium subsp. lithophila in Croatia. 


\section{Discussion}

For the Croatian flora, the species Pimpinella tragium at a specific level was cited by VISIANI (1842:34) in his Flora Dalmatica he wrote »Hab. ad rupes maritimas insulae Lissa«. Afterwards, HIRC (1908) and DomAC (1955) reported this finding for the island of Vis, but without any precise locality. TRINAJSTIĆ (1998) also cited VisIANI's (1842) and PETTER's (1852) localities for the island of Vis. It is clearly evident that nether Domac nor Trinajstić had found $P$. tragium in the flora of the island of Vis. For the island of Svetac, $P$. tragium has been recorded by PAVLetić (1978). According to HIRC (1908:69), potential localities of the species $P$. tragium could be found on the island of Krk and around Rijeka. On these sites $P$. tragium was never confirmed and remain dubious. In ZA and ZAHO herbaria there were no herbarium specimens of this taxon.

Pimpinella tragium subsp. lithophila in Croatia was found along the northern coast of the island of Vis, near the village of Oključina, in the bays of Tiha, Slatina, Mala Travna and Dobra near the town of Vis. These are all littoral localities influenced by the sea spray, where P. tragium subsp. lithophila was found on the calcareous rocky places near the sea. A new taxon grows in the narrow belt along the coast, as a member of halophilous vegetation within Crithmo-Limonion Br.-Bl. et Molinier 1934 alliance. On those sites P. tragium subsp. lithophila grows together with Lotus cytisoides L., Crithmum maritimum L., Limonium subanfractum Trinajstić, Reichardia picroides (L.) Roth, Parapholis incurva (L.) C. E. Hubb., Anthyllis vulneraria (L.) subsp. praepropera (A. Kern.) Bornm., Centaurium erythrea Rafn, Desmazeria rigida (L.) Tutin, D. marina (L.) Druce, Blackstonia perfoliata (L.) Huds., Valantia muralis L., Silene sedoides Poir., Scorpiurus muricatus L., Trifolium angustifolium L., Centaurea issaea Lovrić, Brassica incana Ten., Allium commutatum Guss., Helichrysum italicum (Roth) G. Don and others. Those rocky littorals of the bays Tiha, Slatina, Mala Travna and Dobra are the only know localities of this taxon in Croatia. Recently, the Island of Vis has become an Important Plant Area (IPA) where those sites are included (BogDANOvić and VuKović 2010).

Morphological variability and density of leaf indumentum, as well as leaf incision and geographical pattern of those morphological characters along the whole geographic area of the $P$. tragium, make the taxonomy of the $P$. tragium group difficult. Based on anatomical and morphological study of the $P$. tragium group, two types of plants differing mainly in the hair length on leaves and on the lower part of the stem can be distinguished. P. tragium with hairs $0.05-0.2 \mathrm{~mm}$ long and $P$. polyclada $0.3-1 \mathrm{~mm}$ long (YURTSEVA and TIKHOMIROV 1998). Although the taxonomy of the P. tragium group has been studied by YURTSEVA and TikHOMIRov (1998), it still remains unclear and unresolved. YuRTSEVA and TIKHOMIROV (1998) suggest including $P$. tragium subsp. lithophila and some other subspecific taxa $(P$. tragium subsp. depressa and $P$. tragium subsp. titanophila) of this group under the name of $P$. tragium, while suggesting treating $P$. tragium subsp. polyclada at the specific level as $P$. polyclada Boiss. et Heldr. From a morphological point of view, P. tragium subsp. lithophila has smaller leaf lobes that are 5-10(12) mm long with a deeply serrate margin, while $P$. tragium subsp. polyclada has bigger leaf lobes that are 10-15(20) $\mathrm{mm}$ long and a margin that is not deeply serrate (HARTVIG 1968; TUtin 1968 a, b; Velayos 2003; MATEVSKi 2005). Here we adopt the opinion of Tutin (1968 a, b), Velayos (2003) and MATEVsKi (2005) and treat this new taxon for the Croatian flora at the subspecific level. 


\section{Determination key for Croatian Pimpinella taxa}

Morphological characters and description of the taxon Pimpinella tragium subsp. lithophila were compared with those of $P$. tragium subsp. polyclada, since it is the only known subspecies of this group in Croatian flora. Here we give determination key for the Croatian taxa of the genus Pimpinella:

1 Ovary and fruit glabrous . . . . . . . . . . . . . . . . . 2

- Ovary and fruit pubescent. . . . . . . . . . . . . . . . . . 4

2 Stem usually sharply angled, hollow; ridges of fruit prominent, whitish . . . . P. major

- Stem usually cylindrical, nearly or quite solid; ridges of fruit inconspicuous . . . . . 3

3 Petals on abaxial side pubescent, stem cylindrical, glabrous, hairy only in basal part . . . . . . . . . . . . . . P. saxifraga

- Petals on abaxial side glabrous, stem slightly angled, completely glabrous, shiny . . . . . . . . . . . . . . . . P alpina

4 Plants perennial, stem ligneous at base; with fibres and scale-like leaf bases $P$. tragium 5

- Plants annual or biannual; without fibres or scale-like leaf bases . . . . . . . . . . 6

5 Plant slender; leaf lobes 5-10(12) mm long, margin incise-serrate . . subsp. lithophila

- Plant stout; leaf lobes 10-15(20) mm long, margin not deeply serrate subsp. polyclada

6 Fruit with long patent hairs; umbel with more than 15 rays . . . . . . . . P. peregrina - Fruits with short appressed hairs; umbel with 2-12 rays . . . . . . . . . . . P. anisum

\section{Acknowledgements}

Field investigations were supported by the project »Conservation and Sustainable Use of Biodiversity in the Dalmatian Coast through Greening Coastal Development - COAST «. We extend our thanks to our colleague Igor Boršić, for providing distribution map and comments on the manuscript.

\section{References}

Beck-Mannagetta, G., 1927: Flora Bosnae, Hercegovinae et regiones Novipazar, 3. Choripetalae. Glasnik Zemaljskog Muzeja u Bosni i Hercegovini 63, 1-487.

Bogdanović, S., Vuković, N., 2010: Vis. In: Nikolić, T., Topić, J., Vuković, N. (eds.), Important Plant Areas of Croatia (In Croatian), 454-459. Prirodoslovno-matematički fakultet i Školska knjiga, Zagreb.

Brullo, C., Brullo, S., 2009: Considerazioni su alcune specie critiche della flora sicula. In: Peccenini, S., Domina, G. (eds.), Gruppi critici della Flora d'Italia, 43-44. Società Botanica Italiana, Firenze.

Conti, F., Abbate, G., Alessandrini, A., Blasi, C. (eds.), 2005: An annotated checklist of the Italian vascular flora. Palombi Editori, Roma.

Degen, A., 1937: Flora Velebitica. Verlag der Ungar, Akademie der Wissenschaften, Budapest.

Domac, R., 1994: Flora of Croatia - handbook for plant identification (In Croatian). Školska knjiga, Zagreb. 
DomAC, R., 1955: Flora of the island of Vis (In Croatian). Acta Pharmaceutica Jugoslavica 5, 3-42.

Engstrand, L., 1987: Pimpinella L. In: Rechinger, K. H. (ed.), Flora Iranica 126, 324-325. Graz.

Hartvig, P., 1986: Pimpinella L. In: STRID, A. Mountain flora of Greece 1, 677-680. Cambridge University Press, Cambridge.

HIRC, D., 1908: Revision of Croatian flora (In Croatian). Rad Jugoslavenske Akademije Znanosti i Umjetnosti 173, 38-136.

LukaČ, G., 1997: Pimpinella L. In: Nikolić, T. (ed.), Flora Croatica. Index Florae Croaticae 2. Natura Croatica 6, Suppl. 1, 113.

Matevski, V., 2005: Pimpinella L. In: Micevski, K. (ed.), The flora of the Republic of Macedonia 1(6), 1564-1567. Macedonian Academy of Science and Arts, Skopje.

Matthews, V. A., 1972: Pimpinella L. In: Davis, P. H. (ed.), Flora of Turkey and the east Aegean islands 4, 360-362. Edinburgh University Press, Edinburgh.

Nikolić, T. (ed.), 2010: Flora Croatica database. Department of Botany and Botanical Garden, Faculty of Science, University of Zagreb. http://hirc.botanic.hr/fcd, accessed February 2010.

PAVletić, Zi., 1978: Vascular flora of the island of Svetac (In Croatian). Acta Botanica Croatica 37, 215-224.

PetTer, F., 1852: Insel-Flora von Dalmatien. Oesterreichisches Botanisches Wochenblatt 2,34 .

PignAtTi, S., 1982: Flora d'Italia 2. Edagricole, Bologna.

Qosja, X., PAPAristo, K., Demiri, M., VAngeli, J. (eds), 1992: Flora of Albania (in Albanian). Academie des Science de la République d'Albanie. Le Centre de Researches Biologiques, Tirana.

Rohlena, J., 1942: Conspectus florae Montenegrinae. Preslia 20/21, 1-506.

SARić, M. R., Diklić, N., 1986: Flora of Serbia (In Serbian), 10, Suppl. 2. Srpska akademija nauka i umetnosti, Beograd.

TRINAJSTIĆ. I., 1998: Vascular flora of the island of Vis (In Croatian). Hrvatska Zora, Glasilo Matice hrvatske, Vis 21, 10.

Tutin, T. G., 1968a: Pimpinella L. In: Tutin, T. G. et al. (eds.), Flora Europaea 2, 331-333. Cambridge University Press, Cambridge.

Tutin, T. G., 1968b: Pimpinella tragium Vill. Feddes Repertorium 79, 62.

Velayos, M., 2003: Pimpinella L. In: Castroviejo, S., Nieto Feliner, G., Jury, S. L., Herrero, A. (eds.), Flora Iberica 10, 181-191. Real Jardín Botánico, Madrid.

VISIANI, R., 1852: Flora Dalmatica 3. Lipisiae.

Yurtseva, O. V., Tikhomirov, V. N., 1998: Morphological diversity and taxonomy of the Pimpinella tragium Vill. group (Umbelliferae - Apioideae) in the Mediterranean. Feddes Repertorium 109, 479-500. 